U.S. DEPARTMENT OF HEAL TH, EDUCATION, AND WELFARE

WATIONAL INSTITUTE FOR OCCUPATIONAL SAFETY AND HEALTH

CINC IMUATI, OHIO 45202

HEALTH HAZARD EVALUATION DETERH IMATION REPORT 73-177- - it47

EPC OF ARKAIISAS

FAYETTEVILLE. ARKALISAS

ACTOPER 7974

1. TOKICITY DETERMINATION

Based on the results of enviromental evaluations conducted on January 31 and February 1, 1974, and medica T. evaiuations conducted on May 2, 1974, by the National Institute for Occupational Safety and Health (NioSH), it has been decemined that toxic exposures to sulfuric acid mist and trichloroethylene vapor did not exist at the EPC of Arkansas. Envirommental samples for sulfuric acid and trichloroethylene were well below the 1973 American Conference of Govermental Industriai Hygienists theshold Timit values (TLV) and the Occupational Safety and Heal th Adninistration's standards in the bright dip and degreasing operations. However, since six of ten vorkers interviewed described symptoms of irritation, possib7y due to acid fumes or a combination of irritants, it is suggested that the veritilation should be adjusted to el ininate these exposures.

\title{
Ii. DISTRIBUTION AND AVAILABILITY
}

Coptes of this hazard evaluation detemination are avallable upon reguest from the Hazand Evaluation Services Branch, HIOSH, U.S. Pust oftice Bulditig. Roon 508, 5th and Walnut Streets, Cincinnati, Ohto 45202 . Coptes have been sent to:

(a) EPC of Arkansas

(b) Authorized Representative of Employees

(c) U.S. Department of Labor - Region VI

(d) NIOSH - Region VI

(e) HIOSH - Region VIII

For the purpose of informing approximately 72 exposed emplovees, this report shall be posted in a prominent place readily accessible to wonkers for a period of at least 30 days.

\section{IMTRODUCTION}

Section 20(a)(6) of the 0ccupetionel. Sarety and Heath fict of 1970, 29 U.S.C. 669(a)(6), authorizes the Secretary of Heath, Education, and Welfare. following a witten request by any employer or authomzed representative of emplojees, to detemine whether any substance nomally found in the place of employment has potentidily tox ic effects in such concentrotions as used or found. 
Page 2 - Health Hazard Evaluation Determination Report 73-177

The National Institute for Occupational Safety and Health received such a request from the AlTied Industrial horkers Local Hadis, Fort Simith, Arkansas, to evaluate the potential hazards as socjated with exposure to acids in the bright dip area and from the chlorinated liydrocarbon solvents in the vapor degreasers.

\section{HEALTH HAZARD EVALUATION}

\section{A. Plant Process}

The EPC of Arkansas makes custom-fitted copper pipe fixtures for the plumbing and air conditioning industries. The copper pipe is cut into various lengths and then coated with soap (Ivory Snow has generaily been used). The soap serves as a Tubricant during the bending and shaping process. After the pipe is shaped, it is usually passed through a vapor degreaser. It is then given a brilliant surface by dipping it in a series of bas ic and acidic solutions composed of sodium hydroxide and sulfuric acid, with several water rinses in between. This procedure is known as bright dip. The parts are then dried and packed for shipment.

\section{B. EvâTuation Design}

Prior to the time of the initial survey, it was known that sulfuric acid and trichloroethylene were used in the areas of concern in this hazard evaluation. Sulfuric acid samples were taken by impinger method, using water as a collecting medium and also on polyviryl chloride (PVC) filters. Trich toroethylene samples vere taken, using organic vapor sampting tubes. Idealiy, samples should have been collected for sodium hydroxide and soap dust; however, due to the conclusiveness of the medical findings, it was deemed unrecessary to return and do additional sampling for these compounds.

c. Evaluation Fethods

SuTfuric acid samples were analyzed titrametrically, and the trichloroethylene samples were anaiyzed by gas chromatography in the NIOSH Salt Lake City laboratory.

\section{Evaluation Criteria}

The occupational health standards relevant to the substances of this evaluation, as promuigated by the U.S. Department of Labor (Federal Register, June 27, 1974), are as follows:

\section{8-hour time weighted average}

Substance

Sulfuric Acid

Trichloroethylene

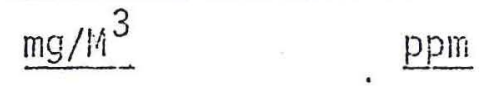

1

$\overline{\mathrm{mg} / \mathrm{m}^{3}}$ - miT7igrams of contaminant per cubic meter of a ir

ppm - parts of vapor or gas per million parts of contaminated air by volune 
Puge 3 - Health Hazard Evaluation Determination Report 73-177

Occupational health standards are established at levels designed to protect individuals occupationally exposed to individual toxic subs tances on an 8-hour per day, 40 mour per week bas is over a nornel working lifetime.

E. Environmental Evaluation Results and Discussion

This evaluation was done on January 37 and February $1,7974$. Samples were taken for trichioroethylene and sulfuric acid. Trich ionoethyiene samples ranged from 2 to 60 ppm, and sulfuric acid samples ranged from 0.05 to $0.15 \mathrm{mg} / \mathrm{m}^{3}$. The results of these sampies substantiated opinions of the Industrial Hyienist and physicians that moppanent health hazard existed at the the of these evaluations.

\section{F. Medical Results and Discussion}

During the walk.through survey of the bright dip area, an unpleasont odor, probably sulfuric acid, wes present. Five workers, all male between the ages of 19 and 42 , were interviewed. These workers had a working experience from two months to two years. Three of these womers reported occastinal nose, throt, and eye irritation. On physical examination no abnomalities of eyes, nose, or throat were observed.

In the area where soap dust was used, five womkers were interviewed, a?! male, whose ages ranged from 28 to 40 jears and whose work experience ranged from 3 months to li years. One worke complaned that inhating soep dust produced a black discharge from his nose; hovever, this could not be observed in the physical examination. One othen worker complaned of sneezing and runing nose on occasion and reported that wearing a disposible surgical-type mask wos effective in preventing this nasal imitation. Another of these workers had severai allergies, including one to soap dust, and weers a surgical-type mask during his work shift and reports that th is is very effective in preventing any symptoms.

During the walk-through survy of this ares, it was noted that the noise ievei was high, approximate ly 95 dBA; and "efforts" were being made to lower this noise level. Ear protectors have been required in the soap dust area but not in the bright dip area for only the past thee months. During the inter. views, it was noted that the most comon type of ear protector was Swedish wool, which was frequent?

Reconmendations:

1. The use of safety glasses and rubber gloves appears to be effective in preventing many accidental spitashes of acids or bases and should be con tinued.

2. Audometric testing should be initiated as a pre-employment as well as a periodic part of the medical program in this plant.

3. When ear protection is used, it wotid be advisable to use devices that have been approved by Nosti. 
Page 4 - Health Hazard Evaluation Determination Report 73-177

V. AUTHORSHIP AND ACKNOHLEDGENT

Report Prepared By:

Bobby U. Gunter, Ph.D. Regional Industrial Hygienist

NIOSH Region VIII - Denver, Colorado

Arnold Bodner, M.D. Miedical officer

NIOSH Hes tern Area Occupationa I Health Laboratory

- Salt Lake City, Utah

Originating office:

Jeroine P. Flesch, Chief Hazard Evaluation Sérvices Branch

- Cincinnati, Onio

Acknouledgment

The authors wish to express appreciation to Win liam Mote. M.D., and to the Salt Lake City laboratory for assistance in this hazond evaluation. 
TABLE I

Breathing Zone Concentrations of Trich Joroethylene

EPC OF ARKANSAS

Fayettevilie, Arkansas

January 31,1974

Job Sample Sample Trichloroethylene

Vol/Liters Number ppm

Degreaser Operator 1 Degreaser operator 2

Degreaser operator 3

Degreaser operator I

Degreaser operator 3

Degreaser Operator 1

Degreaser operator 3

Degreaser Operator 2

Degreaser operator 7

24.4
24.4
24.4
59.5
42.5
42.5
270.0
37.0
60.0

$3 \mathrm{C}$

$4 \mathrm{C}$

$5 \mathrm{C}$

$7 \mathrm{C}$

86

$6 \mathrm{C}$

$10 \mathrm{C}$

$11 \mathrm{C}$

$9 \mathrm{C}$

3

60

37

15

28

10

27

21

Federal Standard

100

1973 ACG IH TLVS

100

C - organic vapor sempling tube 
TABLE II

Breathing Zone Concentrations of Sulfuric Acid

EPC OF ARKANSAS

Fayettevilie, Arkonsas

Feiruary 7,1974

job

Sample Sample Sulfuric Acid $\left(\mathrm{H}_{2} \mathrm{SO}_{4}\right)$

Automatic Dip Line operator 01/Liters Nunber $\mathrm{mg} / \mathrm{M}^{3}$

Fand Cleaning Operator

275

270

Hand Cleaning Operator

Hand Dip Operator

378

470

405

$1 *$
$2 *$
81
82
$8 *$
30

0.15

0.17

$<0.05$

$<0.05$

Automatic oip Ine Operator

30 **

$<0.05$

Federal Standard

1.0

1973 ACGIH TLVS

1.0

* Impinger s amples

$* *$ PVC filter samples 